Article

\title{
Perspectives on Near ZEB Renovation Projects for Residential Buildings: The Spanish Case
}

\author{
Faustino Patiño-Cambeiro ${ }^{1}$, Julia Armesto ${ }^{2, *}$, Faustino Patiño-Barbeito ${ }^{3}$ and Guillermo Bastos ${ }^{3}$ \\ 1 Centro de Ciências Exatas e Tecnológicas, Centro Universitário Univates, Rua Avelino Tallini 171, Lajeado, \\ RS 95900-000, Brazil; faustinopc@uvigo.es \\ 2 Mining Engineering School, University of Vigo, Campus as Lagoas Marcosende, Vigo 36310, Spain \\ 3 Industrial Engineering School, University of Vigo, Rúa Conde de Torrecedeira 86, Vigo 36208, Spain; \\ fpatino@uvigo.es (F.P.-B.); inardesign.gbastos@uvigo.es (G.B.) \\ * Correspondence: julia@uvigo.es; Tel.: +34-986-801-919
}

Academic Editor: Jukka Heinonen

Received: 17 June 2016; Accepted: 2 August 2016; Published: 10 August 2016

\begin{abstract}
EU regulations are gradually moving towards policies that reduce energy consumption and its environmental impact. To reach this goal, improving energy efficiency in residential buildings is a key action line. The European Parliament adopted the Near Zero-Energy Building (nZEB) as the energy efficiency paradigm through Directive 2010/31/EU, but a common technical and legislative framework for energy renovations is yet to be established. In this paper, the nZEB definition by COHERENO was adopted to evaluate several energy renovation packages in a given building, which is also representative of the Spanish building stock. Global costs are calculated for all of them following EPBD prescriptions. Two economic scenarios are analysed: with entirely private funding and with the current public financial incentives, respectively. The results show the divergence between optimum solutions in terms of costs and of minimum $\mathrm{CO}_{2}$ footprint and maximum energy saving. Moreover, in the absence of enough incentives, some inefficient renovations could achieve a global cost close to the optimal cost. The optimum solution both in terms of energy performance and global costs was carried out and described.
\end{abstract}

Keywords: energy efficiency; nZEB; buildings; renovation; cost-optimal

\section{Introduction}

In order to mitigate the adverse effects of climate change, the European Parliament laid down an ambitious common framework to promote the improvement of energy efficiency in buildings through Directive 2010/31/EU [1] (recast), entitled Energy Performance of Buildings Directive (EPBD). It recapitulates the general objectives regarding energy savings and the support for the renewable energy sources included in Renewable Energy Directive 2009/28/EU, as well as the commitment to maintain the long-term global temperature rise below $2{ }^{\circ} \mathrm{C}$. The last step in this direction was taken during the climate change global conference, which ended with the Paris Agreement in December 2015, when 195 nations reached an agreement to set out a global action plan to limit global warming below $2{ }^{\circ} \mathrm{C}$ again, but establishing $1.5^{\circ} \mathrm{C}$ as the reference goal [2].

Buildings are among the most significant energy consumers and greenhouse gas emitters; dwellings, offices, shops, and the rest of public and private buildings generate $36 \%$ of gas emissions and represent $40 \%$ of energy consumption in the EU [3]. They constitute, consequently, one of the main sources of pollution worldwide. The international models of certification that attest to the environmental sustainability of buildings adopt the environmental impact of the building over its life cycle as a key feature. Currently, these certificates meet local criteria (BREEAM, created in the UK [4]; HQE, in France [5]; LIDERA, in Portugal [6]) or have a universal scope, as is the case of the 
American standard known as LEED [7]. These certificates take into account the energy performance of the building as a key feature, nearly reaching $25 \%$ of the certification credits in the case of LEED. The carbon footprint of the building stock in the EU can be significantly reduced, since most of it was constructed according to regulations lacking energy efficiency guidelines; they were aimed at ensuring comfort for users instead of establishing a legislative framework to develop a sustainable construction industry.

In addition to the absence of binding regulations, the high investments that efficiency measures require have resulted in a poor penetration of energy rehabilitations. There are scarce data on the number of renovations being undertaken in Europe, their depth, or the trends in renovation rates. However, given that construction and, therefore, changes in Buildings Codes are long-term processes, the overall EU renovation rate of the building stock is probably not far from the $1 \%$ estimated in the study conducted by the Fraunhofer Institute on the Energy Savings Potentials in EU Member States in 2009 [3]. This opportunity for energy and environmental savings in buildings led the European Parliament to develop regulation directives (Directive 2009/28/EU, Directive 2012/27/EU) that could lay the foundations for promoting significant improvements in the energy performance of the European building stock. In line with the EU objectives in this field, the European Alliance of Companies for Energy Efficiency in Buildings (EuroACE) initiated the Renovate Europe Campaign. It aspires to reduce the energy demand from the EU building stock by $80 \%$ by 2050 , compared to 2005 . This is expected to be accomplished by encouraging major renovations in order to triple the EU average renovation rate from the current $1 \%$ to $3 \%$ before 2020 [8].

The EPBD constitutes the main reference in the European building energy policy. It calls for member states to develop national plans in order to encourage the improvement of the energy efficiency of buildings, taking into account outdoor climatic and local conditions, as well as indoor climate requirements and cost-effectiveness. Two fundamental concepts are introduced in the EPBD. One is the Near Zero-Energy Building (nZEB), a building that achieves the benchmark efficiency by pursuing or outperforming a list of technical requisites. On the other hand, and linked to the former, is the concept of cost-optimal: the package of efficiency measures chosen must be the one that leads to the minimum cost during the estimated economic life cycle of the building. The concept of cost-optimal refers both to that minimum global cost and to the methodology prescribed.

The EPBD requires new buildings to be nZEBs by the end of 2018 or 2020, depending on their ownership. Despite the fact that until 2014 several European countries had adopted financial instruments such as financial subsidies, subsidised mortgage interest for efficient homes, and low-interest loans for retrofitting [9], many studies still conclude that a greater effort is needed to promote efficiency in both new and renovated buildings. For instance, according to Dineva et al. [10], in the Netherlands, Sweden, and France the availability of public funds is insufficient, and alternative measures such as credit lines providing soft loans, tax exemptions, or support schemes for third-party financing are often scarce. Many examples across Europe are mentioned and discussed in [11-13].

This paper studies the feasibility of nZEB renovations by analysing their global cost. A real refurbishment of a building from 1974 located on the northwest coast of Spain is described, for which different viable packages of efficiency solutions were considered in order to be upgraded to the nZEB category according to precise technical requirements. In this way, the rehabilitation costs and the simulated energy demand and consumption can be properly validated. This article is organized as follows: the next section analyses the term nZEB, the concept of "efficient building" set as a goal by the $\mathrm{EU}$, and the economic barriers that limit the penetration in the market of such efficient buildings. Section 3 details the case study. The cost-optimal methodology is described in Section 4, as well as the available financial support in Spain. In Section 5 the different renovation schemes are presented and their feasibility is compared within two different scenarios: with private funding or public financial support. Section 6 discusses the results obtained and, finally, the conclusions are presented in Section 7. 


\section{Considerations about the nZEB Concept}

The European Union EPBD introduced the concept of nZEB, which is described as a highly efficient building, but not enough to reach the key feature of a sustainable building: the balance between generated and consumed energy. The definition of nZEBs was intentionally open, as it is the result of a political commitment acknowledging the variety of EU building traditions and the discrepancies between the levels of development among its members [14].

The EPBD points out the energy elements and thermal characteristics to be taken into account, but explicitly delegates the elaboration of a numerical magnitude of the primary energy used to each European member state. In response to the directive's vagueness, several governmental and non-governmental organizations, as well as research groups, are trying to establish an internationalised definition that facilitates all members in implementing the requirements for nZEBs in their own regulations. To this end, it is necessary to describe the nZEB as a function of all the parameters that cause divergence among the definitions: the function and size of the building, the location, the climate, the cultural and economic background of the country, etc. Internationally adopted criteria would eliminate barriers to public and private collaboration. Moreover, they would provide a basis for developing a framework for inspections and certifications that would increase customer confidence through quality assurance mechanisms.

According to the report ordered by the European Commission to a consortium led by Ecofys [15], a large variety of concepts for nZEBs were conceived. Apart from the United Kingdom, where the aim since 2016 is zero-carbon emissions in the national Level 6 of the Code for Sustainable Homes [16], most European states do not set requirements for an energy rating or detail an energy performance indicator. They calculate a yearly energy balance based on procedures that do not fit in every case into the EPBD formulations: different metrics are used (site energy, primary energy, costs, or emissions), different boundaries for the primary energy and renewable energy are taken into account, and the house area is computed from different variables. In conclusion, a great deal of work is still necessary to move towards a harmonized framework for the technical description of the nZEB concept in Europe. After the publication of the report by Ecofys in 2013, D'Agostino [9] reviewed in 2014 the progress of the nZEB normalisation. She concluded that progress is evident in many member states compared to the first attempt to launch a national definition, but coherency could not yet be found: differences regarding the metric of balance, the system boundary, the area of the building considered, the balance period, etc. were still present. Figure 1 shows the technical aspects, the combination of which results in the broad range of definitions.

Since the adoption of the EPBD, several papers have studied the efficiency of buildings from the point of view of the nZEB benchmark. Some of them pointed out the need to define this concept more precisely. In the research field, there are case studies of new constructed nZEB dwellings [17], or the renovation of a single family house to achieve the nZEB level in the Mediterranean region [18,19]. Lindkvist et al. [20] presented an extension of the nZEB concept to the near Zero-Energy Neighbourhood; the authors concluded that, although this constitutes an area with opportunities for intervention, the knowledge of nZEB renovations is not being transferred and financial and social barriers should be addressed.

Alongside the complex task of standardising the nZEB concept all over Europe, an additional difficulty arises when applying an energy standard to existing buildings. Adapting structural, enclosure, and energy generation components requires a more detailed analysis than selecting them for a new building. For this reason, it is worth emphasising the proposal conceived by COHERENO, a panel made up of research institutes and advisory bodies from Austria, Belgium, Germany, The Netherlands, and Norway. This organisation has defined the nZEB renovation of a house as that which has any of the following characteristics [21]:

(1) The energy performance of the building after the renovation fulfils the nZEB requirements for new buildings established by the Member State or Region. 
(2) The energy demand for heating/cooling, domestic hot water (DHW), and ventilation energy consumption of auxiliary building's systems is not more than $50-60 \mathrm{kWh} / \mathrm{m}^{2} /$ year.

(3) The primary energy consumption of the building after the renovation is reduced by $75 \%$ compared to the original performance.

(4) At least $50 \%$ of the energy demand is covered by renewable energy sources.

(5) The $\mathrm{CO}_{2}$ emissions associated with energy consumption remain below $3 \mathrm{kgCO}_{2} / \mathrm{m}^{2} /$ year.

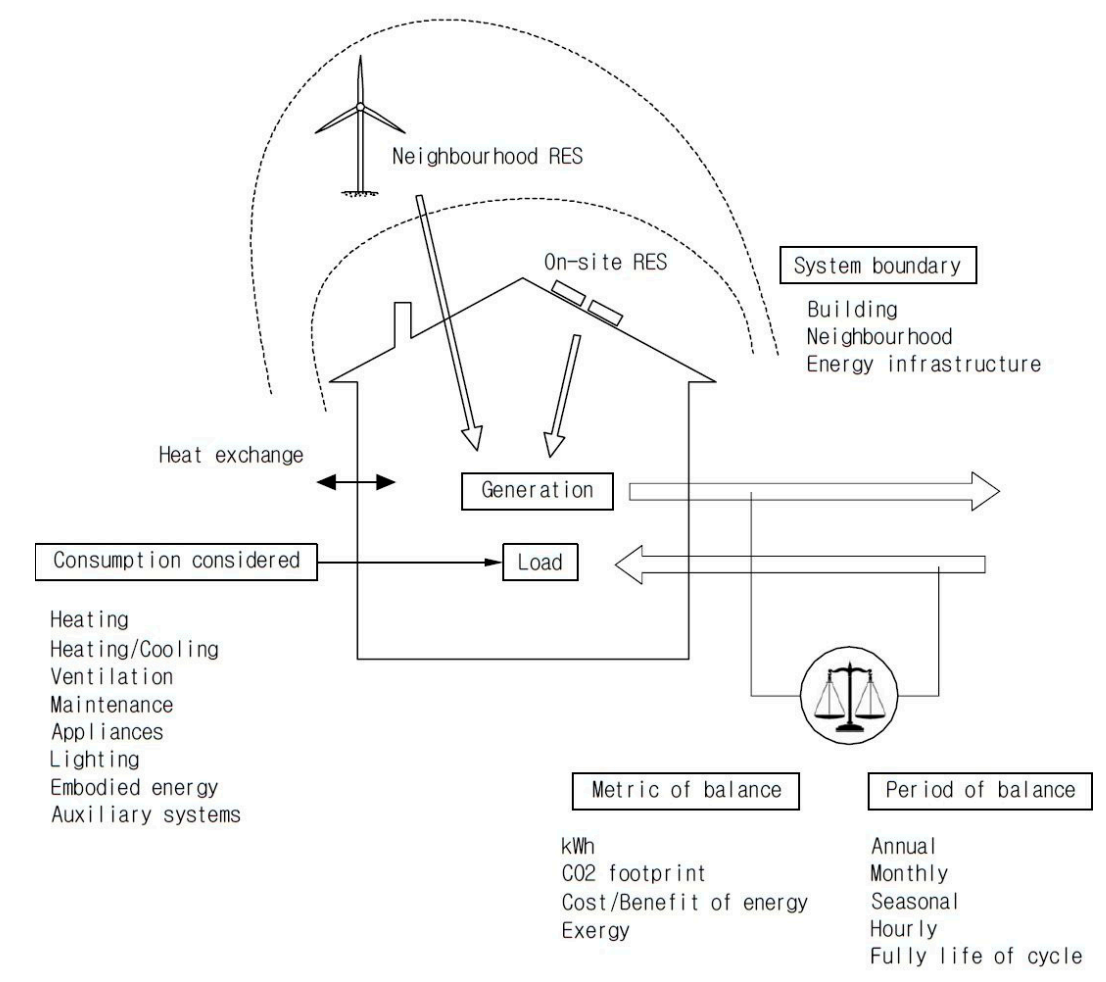

Figure 1. Parameters taken into account for different definitions of nZEB.

Since the definition provided by COHERENO for nZEBs is explicitly addressed to renovations and is one of the most precise at the moment, it was chosen in this piece of work to compare the packages of measures that make the building fall within the nZEB category with the packages that imply the minimum cost according to the EPBD cost-optimal methodology [22].

\section{Case Study}

This paper assesses the energy performance and costs of several renovation schemes in different economic scenarios for a representative case of the Spanish building stock. The majority of Spanish residential buildings suffer from the deficiencies in energy performance previously pointed out. Nearly 55\% of buildings were constructed before 1979 (see Figure 2), the starting date when thermal insulation was declared compulsory for buildings in accordance with the national Construction Code. Apart from building envelope insulation, the other serious chronic deficiency resides in the heating system. Until 2001, 46\% of Spanish dwellings were using electric heating [23].

The building analysed is located in A Guarda, on the Atlantic coast of Spain (see Figure 3). It was built in 1974. It consists of five storeys with two flats per floor; their combined living area is $568 \mathrm{~m}^{2}$. Before the energy renovation, each flat was provided with electric heating and DHW was supplied by lo-efficiency gas boilers. The most relevant data regarding the initial conditions are presented in Table 1 . The number of living floors, living area, and heating and DHW systems are common characteristics among the buildings constructed in the same period. 
$6,000,000$

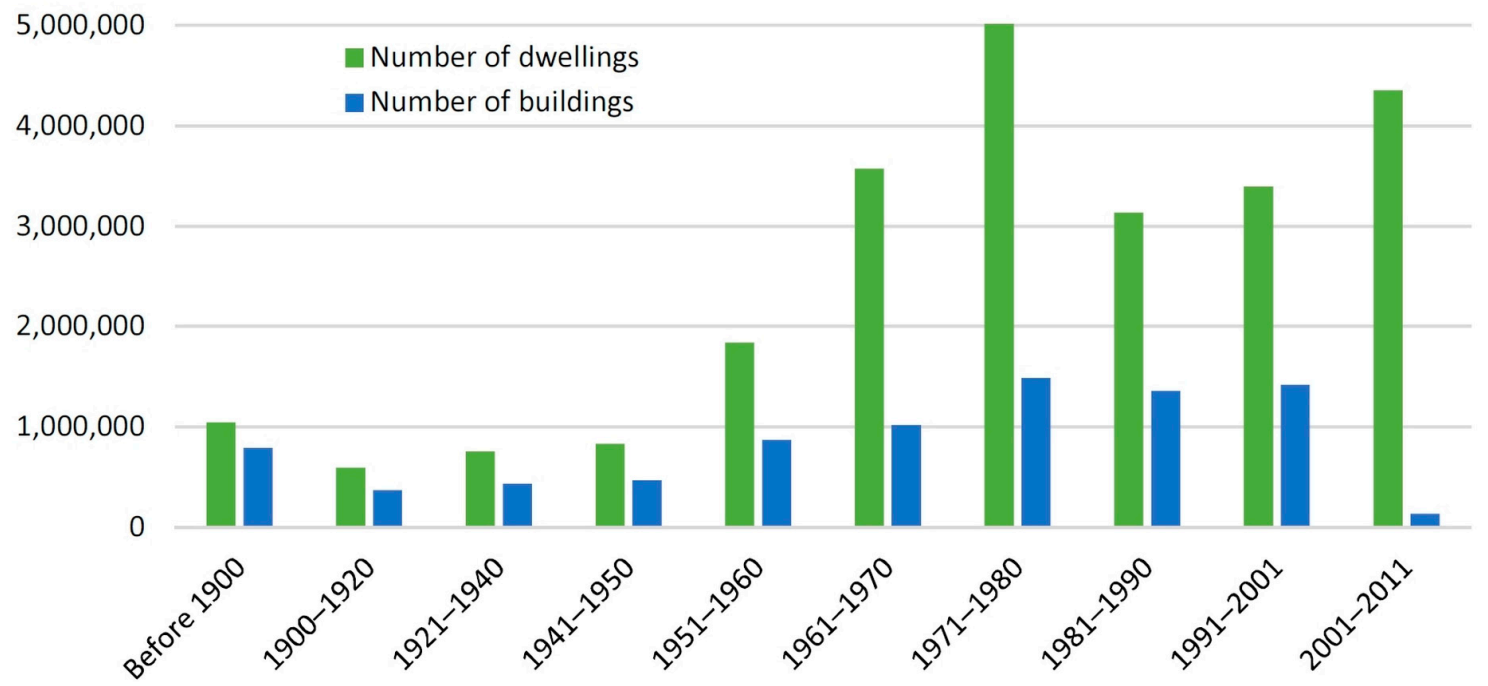

Figure 2. Evolution over time of the ratio between newly constructed buildings and dwellings in Spain (data obtained from the National Institute of Statistics, INE).

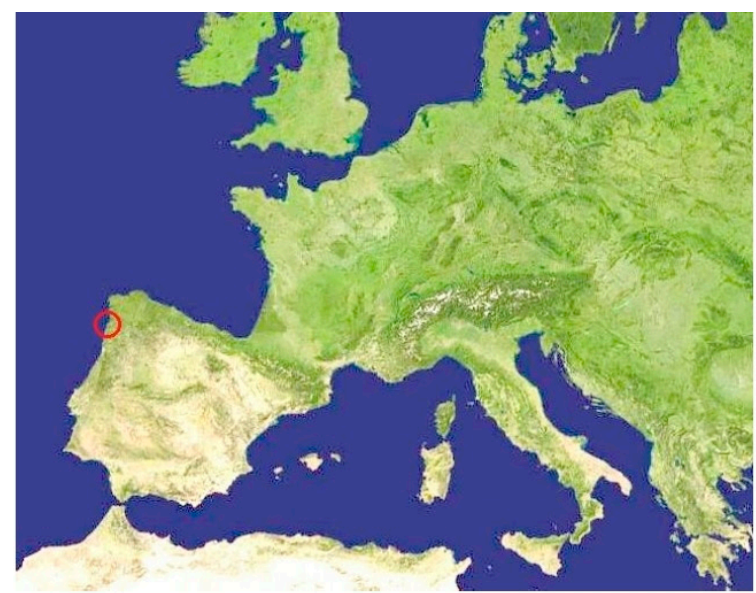

(a)

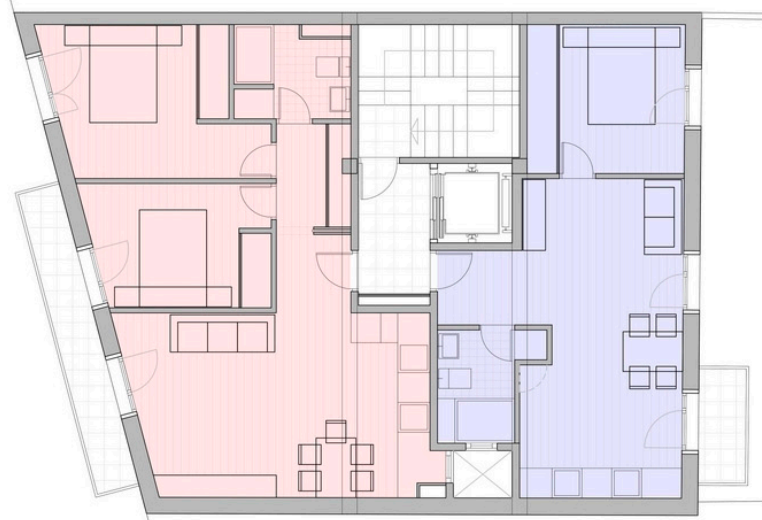

(b)

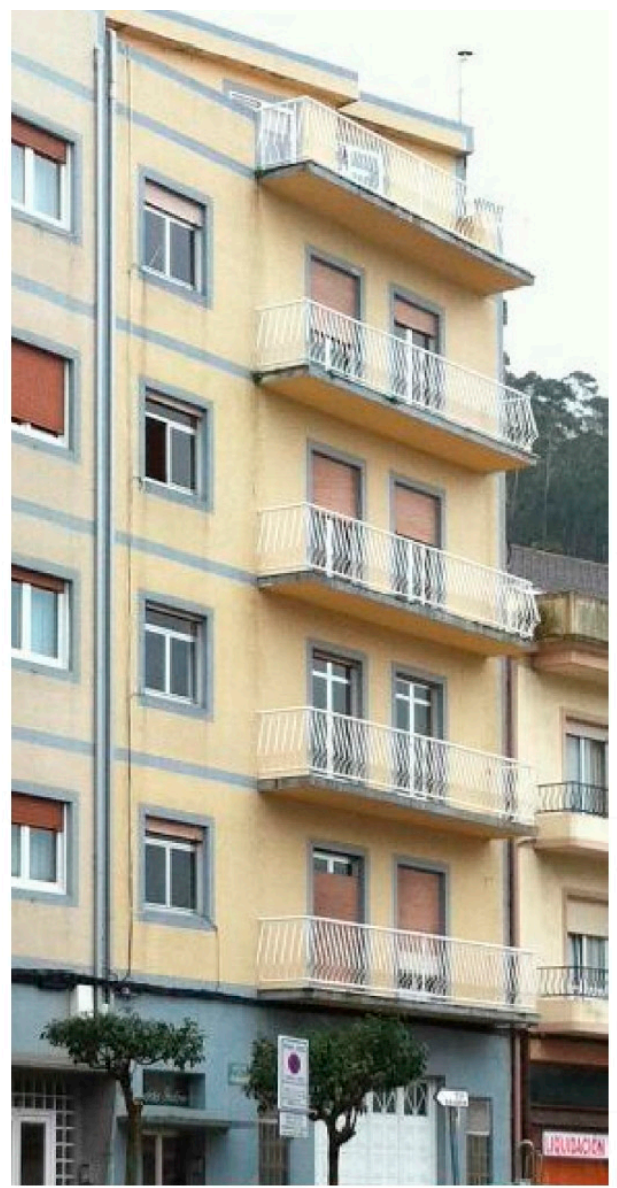

(c)

Figure 3. Details of the analysed building: (a) location of the building: A Guarda, Spain (source: www.zonu.com); (b) plan view after renovation; (c) façade before renovation. 
Table 1. Baseline data of the building.

\begin{tabular}{cc}
\hline Location & A Guarda, Spain \\
Type of building & Condominium \\
Year of construction & 1974 \\
Climate zone (Code HE-1) & $\mathrm{C} 1$ \\
Living area & $568 \mathrm{~m}^{2}$ \\
Number of living floors & 5 \\
Number of dwellings & 10 \\
& $\mathrm{~N}-\mathrm{W}$ façade: $138 \mathrm{~m}^{2}$ \\
Geometry of the building & $\mathrm{N}-\mathrm{E}$ façade: $36 \mathrm{~m}^{2}$ \\
& S-W façade: $61 \mathrm{~m}^{2}$ \\
& S-E façade: $139 \mathrm{~m}^{2}$ \\
Heating system & Electric \\
DHW system & Butane \\
\hline
\end{tabular}

\section{Methodology}

An energy model of the building is constructed through CE3X, the official tool recognised by the Spanish Government to obtain the energy efficiency certificate for existing buildings. This tool is based on the Energy Plus simulation engine. Table 2 compiles the energy parameters that outline the performance of the original energy systems and thermal insulation of the analysed building. This information provides an insight into the opportunities for improvement. Next, based on this information, a set of renovation packages of efficiency improvement measures was considered and evaluated.

Table 2. Technical and energy performance data of the building (from the CE3X software).

\begin{tabular}{cc}
\hline Variable & Value \\
\hline Primary Energy Demand & $91.9 \mathrm{kWh} / \mathrm{m}^{2} /$ year \\
Primary energy consumption & $305.32 \mathrm{kWh} / \mathrm{m}^{2} /$ year \\
Energy consumption in heating & $266.43 \mathrm{kWh} / \mathrm{m}^{2} /$ year \\
Energy consumption in DHW & $38.89 \mathrm{kWh} / \mathrm{m}^{2} /$ year \\
Carbon footprint & $75.04 \mathrm{kgCO} / \mathrm{m}^{2} /$ year \\
\hline
\end{tabular}

The process that enables the identification of the optimum renovation packages, in economic and energy terms, consists of the following steps:

(1) Identification of feasible renovation solutions from a technical point of view.

(2) Definition of the working packages resulting from the combination of the considered renovation solutions.

(3) Calculation of the energy efficiency, in terms of energy demand and consumption, for every working package. The fulfilment of COHERENO requirements is checked for each package.

(4) Calculation of the global cost for each package of renovation measures. The economic evaluation is obtained for two scenarios: the first considers $100 \%$ private financing and the second considers the available public financial support.

(5) Determination of the packages with the global cost that is closer to cost-optimal, obtained within the calculation framework provided by the EU Delegated Regulation 244/2012 [22].

(6) Both the cost-optimal and the compliance with COHERENO for nZEB conditions are checked.

The reason to consider two scenarios, with and without supporting programmes, lies in the results from different authors who have performed calculations for diverse nZEB. Different authors have performed calculations for diverse nZEB case studies based on the NPV tool. For instance, Kmet'ková et al. [24] obtained significant differences between scenarios depending on the availability of tax incentives and funding support. 


\subsection{Cost-Optimal Calculation}

In order to determine the packages of renovation measures that achieve an optimum balance between investment, energy savings, and environmental impact, a comprehensive study of their economic viability is usually the first step to take. To this end, Life Cycle Costing (LCC) is a commonly used decision criteria. LCC evaluates the cost-performance of a building throughout its life cycle, including acquisition, development, operation, management, repair, disposal, and decommissioning. To enable its practical use in the construction industry, ISO 15686-5 establishes a clear terminology and a common methodology of LCC $[25,26]$. LCC was applied, for example, to point out the higher cost-effectiveness of energy-saving measures compared to on-site PV energy sources [27,28]. A comparison between LCC and different life cycle methodologies aimed at estimating the economic feasibility of nZEBs was carried out by Sesana et al. [29].

Among cost methodologies, the Net Present Value (NPV) is the traditional equation to manage the initial and future costs incurred in a project. It consists in determining the present value of an investment through the sum of future cash flows discounted yearly. Since it is a fundamental tool for investment appraisal, it is widely applied in the field of energy renovations of buildings [30,31]. Once again, the method can be adapted to the field of building renovation, for instance by considering the increase in the property value after completing the renovation [32]. Nonetheless, NPV and, consequently, LCC present some limitations because of the lack of reliable information and the difficulty in establishing predictions regarding the interest rate, the costs of available energies, and, even, the estimation of the life cycle of a building [29]. For instance, a small change in the interest rate can dramatically modify the calculated NPV, given the variation of cash value over time. In the case of building renovation, NPV is frequently negative, i.e., the renovation becomes economically unfeasible. Nonetheless, and apart from the economic criteria, the most relevant models of certification consider the social and environmental criteria by means of parameters regarding comfort, health, personal preferences, or the increased global value increase of the building. Since there is still no internationally accepted technical guidance on requirements and calculations of energy renovations, in this paper we have followed the cost-optimal methodology established by the EU Delegated Regulation 244/2012 [22], which complements the EPBD. It takes for granted certain simplifications, such as adopting a fixed period of calculation.

The "cost-optimal level" is defined in the EPBD as the energy performance level which leads to the lowest cost during the estimated economic life cycle. The cost-optimal framework comprises two different approaches to cost calculations: one from a macroeconomic level and another one from a financial point of view. In our case, the financial calculation is the most suitable tool because it is based on the consumer's perspective. The cost-optimal approach comprises all the costs charged to the client, including all applicable taxes, and is expressed as the sum of the following categories [22]:

- Initial investment costs;

- Energy costs and savings and earnings from surplus of renewable energy, where applicable;

- Maintenance costs;

- Replacement costs for periodic replacement of building elements and disposal costs where applicable.

All costs and savings are discounted at the beginning of the calculation period using the NPV method, i.e., using a discount rate. The residual value shall be determined by a straight-line depreciation of the investment in building elements until the end of the calculation period; alternatively, the disposal costs will be taken into account. The calculation period established for residential buildings is 30 years. In the financial approach the cost-optimal is expressed as the global $\operatorname{cost} C_{g}$, for each working package $j$, through the following expression:

$$
C_{g}=C_{j}+\sum_{j}\left[\sum_{i}\left(C_{a, i}(j) \times R_{d}(i)\right)-V_{f, \tau}(j)\right],
$$


where:

- $C_{j}$ means initial investment costs,

- $C_{a, i}(j)$ are the net annual costs,

- $\quad R_{d}$ is the discount factor for year $i$ based on the discount rate $r: R_{d}(i)=\left(\frac{1}{1+\frac{r}{100}}\right)^{i}$,

- $V_{f, \tau}(j)$ means the residual value of the set of measures $j$ at the end of the calculation period.

In order to evaluate the economic feasibility of the considered packages for energy renovation solutions, and to identify the cost-optimal option, two groups of input parameters are needed: the prices of available energies and the economic parameters. They are presented in Table 3.

Table 3. Input parameters.

\begin{tabular}{|c|c|c|c|c|}
\hline \multicolumn{3}{|c|}{ Energy Costs } & \multicolumn{2}{|l|}{ Financing Parameters } \\
\hline Energy Source & Price (VAT Included) $€ / \mathrm{kWh}$ & Increase (\%) & Parameter & Value \\
\hline Electricity ${ }^{1}$ & 0.15 & 4.50 annual & Inflation rate & $2.00 \%$ \\
\hline LPG (butane) ${ }^{2}$ & 0.079 (January-April) & -1.6 bimonthly & Bank interest rate & $6.80 \%$ \\
\hline Natural gas ${ }^{1}$ & 0.051 & 3.00 annual & Discount rate & $3.00 \%$ \\
\hline Biomass (pellets) ${ }^{3}$ & 0.057 & 2.00 annual & Period of calculation (years) & 30 \\
\hline
\end{tabular}

\subsection{Current Public Financial Scheme for Energy Renovation of Buildings in Spain}

The European Parliament established that the states might develop economic incentives to promote energy renovation of buildings. In the Spanish case, the financial scheme is known as PAREER-CRECE [33]. It will be active up to the end of 2016. It is aimed at promoting renovations that improve energy savings, energy efficiency, the use of renewable energy sources, and the reduction of $\mathrm{CO}_{2}$ emissions. The plan focuses on the following lines of action:

(1) Improving the energy efficiency of the thermal envelope.

(2) Improving the energy efficiency of the thermal installations and the lighting system.

(3) Replacing conventional energy sources with biomass energy for thermal installations.

(4) Replacing conventional energy sources with geothermal energy for thermal installations.

In our case study, the applicable lines of action are items 1 and 3; their eligible amounts are presented in Table 4 . The amount of public funding slightly depends on the energy certificate. Concepts are cumulative. Consequently, if two or more measures are accomplished, $90 \%$ of funding can be achieved.

Table 4. Eligible amounts of the Spanish scheme PAREER-CRECE for the promotion of energy renovations.

\begin{tabular}{|c|c|c|c|c|c|c|}
\hline \multirow{4}{*}{ Typology } & \multicolumn{5}{|c|}{ Non-Refundable Subsidy } & \multirow{4}{*}{$\begin{array}{c}\text { Refundable } \\
\text { Subsidy }{ }^{1}\end{array}$} \\
\hline & \multirow{3}{*}{$\begin{array}{c}\text { Base } \\
\text { Subsidy }\end{array}$} & \multicolumn{4}{|c|}{ Extra Funding } & \\
\hline & & \multicolumn{3}{|c|}{ Certificate after Renovation } & \multirow{2}{*}{$\begin{array}{l}\text { Complete } \\
\text { Renovation }\end{array}$} & \\
\hline & & A & B & +2 Letters & & \\
\hline Thermal envelope & $30 \%$ & $15 \%$ & $10 \%$ & $5 \%$ & $20 \%$ & $60 \%$ \\
\hline Replacement with biomass ${ }^{2}$ & $25 \%$ & $0 \%$ & $0 \%$ & $0 \%$ & $10 \%$ & $65 \%$ \\
\hline
\end{tabular}

Notes: ${ }^{1}$ Interest rate is EURIBOR. Maximum repayment term is 12 years; ${ }^{2}$ For the purposes of calculating the financial contribution for line of action No. 3, the maximum eligible cost would be deducted from expression: $C=880 \times P^{0.87}(€)$, where $P$ is the power of the biomass boiler in $\mathrm{kW}$. 


\section{Results}

\subsection{Rehabilitation Solutions and Working Packages}

For the analysed case, five energy rehabilitation solutions were both economically and technically viable. They are listed in Table 5, together with the initial conditions, which represent package No. 0 . Three measures are active and two of them are passive. By combining these variables, 18 working packages were obtained.

Table 5. Renovation solutions in terms of working packages.

\begin{tabular}{|c|c|c|c|c|c|}
\hline Working Package & INS $^{1}$ & FRA $^{2}$ & GAS $^{3}$ & $\mathrm{BIO}^{4}$ & SOLAR $^{5}$ \\
\hline 0 & - & - & - & - & - \\
\hline 1 & & & $x$ & & \\
\hline 2 & & & $x$ & & $X$ \\
\hline 3 & & & & $x$ & \\
\hline 4 & & & & $X$ & $x$ \\
\hline 5 & $x$ & & & & \\
\hline 6 & $x$ & & $x$ & & \\
\hline 7 & $x$ & & $x$ & & $x$ \\
\hline 8 & $X$ & & & $x$ & \\
\hline 9 & $x$ & & & $x$ & $x$ \\
\hline 10 & & $X$ & & & \\
\hline 11 & & $X$ & $x$ & & \\
\hline 12 & & $X$ & $X$ & & $X$ \\
\hline 13 & & $X$ & & $x$ & \\
\hline 14 & & $x$ & & $x$ & $X$ \\
\hline 15 & $x$ & $x$ & $X$ & & \\
\hline 16 & $x$ & $X$ & $x$ & & $x$ \\
\hline 17 & $x$ & $x$ & & $X$ & \\
\hline 18 & $x$ & $x$ & & $x$ & $x$ \\
\hline
\end{tabular}

\subsection{Evaluation of Energy Performance for Renovation Packages}

The effects on primary energy demanded and consumed by each renovation package are summarised in Table 6 below, where those working packages that fulfil the COHERENO requirements are highlighted in green. Calculations were made with the CE3X tool. It should be emphasised that despite the fact that packages No. 3 and 4 satisfy the COHERENO condition regarding emissions, the demand for primary energy has not been reduced at all compared to the initial condition. Only packages No. 17 and 18 satisfy the 75\% energy saving requirement; additionally, these two packages satisfy the other four COHERENO conditions, so they can be considered the optimum from the energy point of view. 
Table 6. Energy performance of working packages. Fulfilment of COHERENO requirements is highlighted in green.

\begin{tabular}{|c|c|c|c|}
\hline Working Package & $\begin{array}{c}\text { Primary Energy } \\
\text { Demand }\left(\mathrm{kWh} / \mathrm{m}^{2} / \text { year }\right)\end{array}$ & $\begin{array}{c}\text { Primary Energy } \\
\text { Consumption }\left(\mathrm{kWh} / \mathrm{m}^{2} / \text { year }\right)\end{array}$ & $\begin{array}{l}\mathrm{CO}_{2} \text { Emissions } \\
\left(\mathrm{kgCO}_{2} / \mathrm{m}^{2} / \text { year }\right)\end{array}$ \\
\hline 0 & 91.5 & 350 & 53.3 \\
\hline 1 & 91.5 & 175 & 36.9 \\
\hline 2 & 91.5 & 164 & 34.6 \\
\hline 3 & 91.5 & 143 & 2.4 \\
\hline 4 & 91.5 & 134 & 2.3 \\
\hline 5 & 62.5 & 258 & 40.5 \\
\hline 6 & 62.5 & 131 & 27.6 \\
\hline 7 & 62.5 & 120 & 25.3 \\
\hline 8 & 62.5 & 107 & 1.8 \\
\hline 9 & 62.5 & 98 & 1.7 \\
\hline 10 & 78.3 & 308 & 47.5 \\
\hline 11 & 78.3 & 155 & 32.7 \\
\hline 12 & 78.3 & 144 & 30.4 \\
\hline 13 & 78.3 & 127 & 2.6 \\
\hline 14 & 78.3 & 118 & 2.2 \\
\hline 15 & 45.7 & 106 & 20.0 \\
\hline 16 & 45.7 & 95 & 17.7 \\
\hline 17 & 45.7 & 76.39 & 1.6 \\
\hline 18 & 45.7 & 77.43 & 1.4 \\
\hline
\end{tabular}

\subsection{Economic Evaluation in the Absence of Financial Incentives}

The initial economic conditions that are assumed for this case consist of private funding through a loan at $6.8 \%$ interest rate for 10 years. The overall costs of each renovation package are presented in Table 7 and the representation of primary energy consumption in comparison with overall costs is shown in Figure 4.

Table 7. Global costs of the 18 working packages with no financial support $\left(€ / \mathrm{m}^{2}\right)$.

\begin{tabular}{cccc}
\hline Working Package & Global Costs $\left(\boldsymbol{\epsilon} / \mathbf{m}^{\mathbf{2}}\right)$ & Working Package & Global Costs $\left(\boldsymbol{\epsilon} / \mathbf{m}^{\mathbf{2}}\right)$ \\
\hline 1 & 429 & 10 & 529 \\
2 & 480 & 11 & 750 \\
3 & 469 & 12 & 573 \\
4 & 521 & 13 & 521 \\
5 & 522 & 14 & 479 \\
6 & 572 & 15 & 529 \\
7 & 576 & 16 & 831 \\
8 & 525 & 17 & 571 \\
9 & 479 & 18 & 622 \\
\hline
\end{tabular}

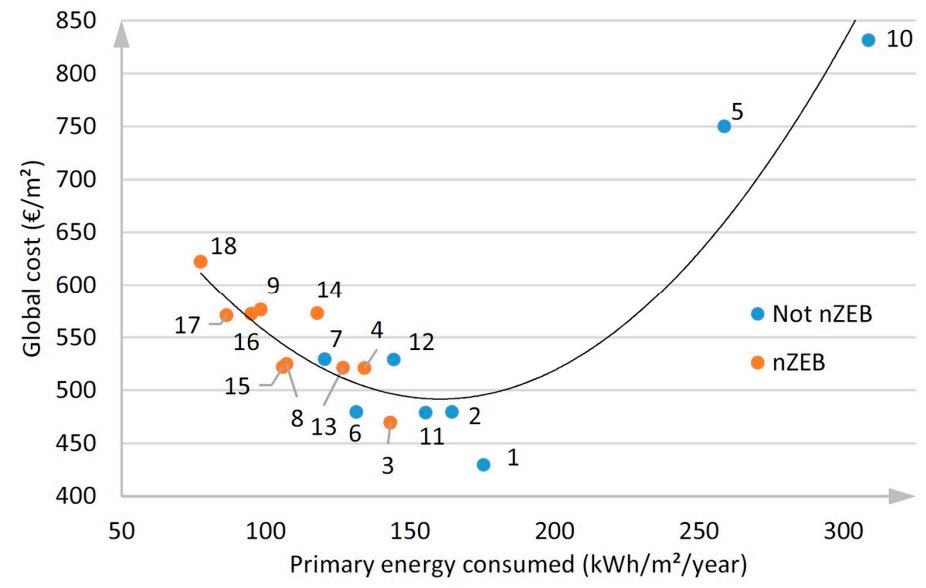

Figure 4. Global costs incurred in absence of financial support. 
The cost-optimal can be easily identified in renovation package No. 1, which consists of replacing the original heating and DHW sources with a central standard gas boiler of $56 \mathrm{~kW}$. This boiler would supply underfloor heating. Energy demand would not be reduced at all since the thermal envelop would not be upgraded. Primary energy consumption would be reduced to $175 \mathrm{kWh} / \mathrm{m}^{2} /$ year and the global cost would be $429 € / \mathrm{m}^{2}$. The repayment period would be approximately eight years, one of the shortest among the 18 alternative renovations. However, package No. 1 does not comply with any of the COHERENO prerequisites to be considered a nZEB renovation.

\subsection{Economic Evaluation in a Scenario with Financial Incentives}

The analogous calculation process to the previous scenario is carried out, but in this case the available funding incentives described in Section 5.1 are considered for each package. Results are shown in Table 8. The comparison between Tables 7 and 8 reveals that costs are significantly lower in the incentives scenario. Figure 5 represents primary energy consumption in comparison with the new global costs. In this case, package No. 17 would represent the cost-optimal. This package consists of renovating the thermal envelope and the window carpentry, retrofitting the heating system with underfloor heating, and supplying the heating and DHW through a high-efficiency biomass boiler. This solution would cost $412 € / \mathrm{m}^{2}$ and it would comply with all COHERENO requisites to become an nZEB renovated home. Thus, package No. 17 was chosen to upgrade the energy performance of the building studied in this paper.

Table 8. Global costs of the 18 working packages with financial support $\left(€ / \mathrm{m}^{2}\right)$.

\begin{tabular}{cccc}
\hline Working Package & Global Costs $\left(\boldsymbol{\epsilon} / \mathbf{m}^{\mathbf{2}}\right)$ & Working Package & Global Costs $\left(\boldsymbol{\epsilon} / \mathbf{m}^{\mathbf{2}}\right)$ \\
\hline 1 & 429 & 10 & 478 \\
2 & 480 & 11 & 702 \\
3 & 444 & 12 & 489 \\
4 & 495 & 13 & 438 \\
5 & 434 & 14 & 442 \\
6 & 484 & 15 & 492 \\
7 & 471 & 16 & 795 \\
8 & 419 & 17 & 412 \\
9 & 428 & 18 & 463 \\
\hline
\end{tabular}

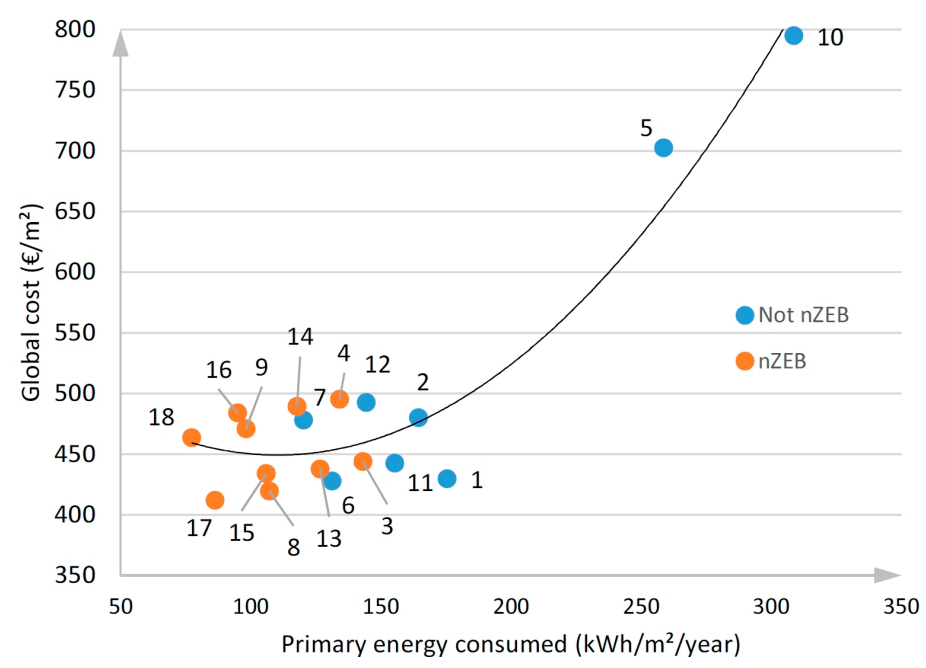

Figure 5. Global costs including current financial support. 


\subsection{Execution of the Optimum nZEB Renovation}

The building underwent a complete renovation, which corresponds to package No. 17. It started with the modification of the interior partitions to improve accessibility, in line with sustainability targets. Thermal improvements consisted of the installation of a thermal shell along its entire perimeter and the upgrade to new windows with aluminium frames, a thermal break, and low-emissivity glass. Energy coverage switched from individual electric heaters to a central biomass boiler of $56 \mathrm{~kW}$, which provides floor heating and DHW. Once the renovation project was finished and all the flats were rented, the energy performance of the building was tested and the theoretical results were verified.

Insulation was verified through thermographic inspection, considering the twin building next to the analysed one as a reference. Figure 6 gives thermographies of both façades, resulting in a difference of $1.7^{\circ} \mathrm{C}$ between the surfaces' temperatures. It shows the reduction of the thermal transmittance value provided by the ETICS façade solution.

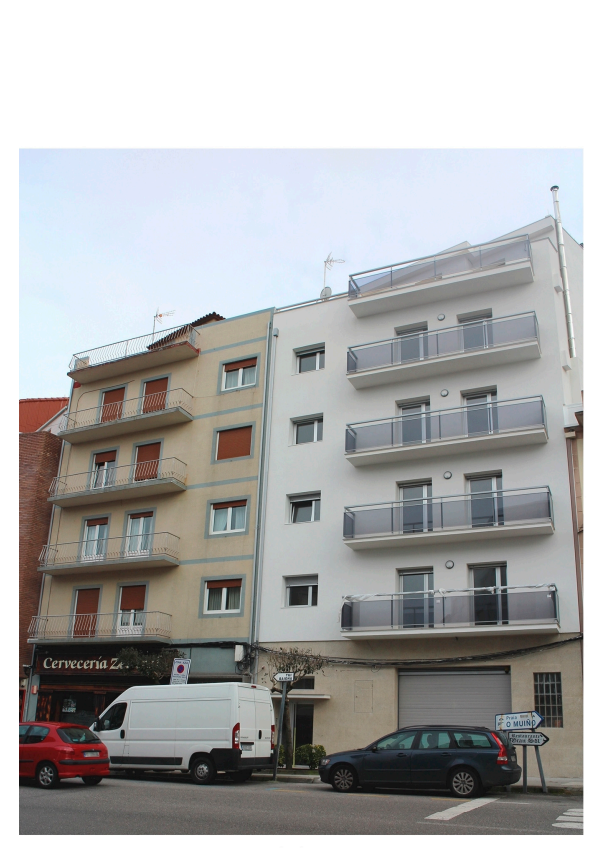

(a)

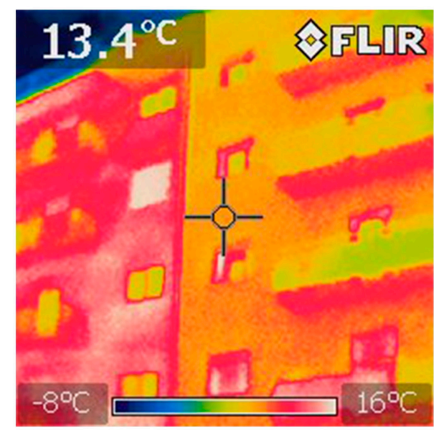

(b)

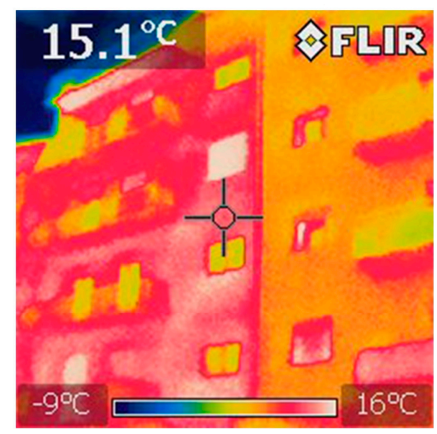

(c)

Figure 6. (a) Optical image of the renovated building façade and the twin building façade (original condition); (b) thermography showing the façade surface temperature at the cross point over the renovated building; and (c) over the twin building.

\section{Discussion of the Results}

Once the EPBD global costs have been obtained, they can be compared to the initial investment costs. Several packages have a similar global cost to package No. 17, which is the optimum in terms of energy saving. However, their initial investment costs are substantially lower. The initial investments for packages No. 1, 6, and 17 are shown in Figure 7. Renovation package No. 17 requires an initial investment of $182 € / \mathrm{m}^{2}$, i.e., $32 \%$ higher than the $123 € / \mathrm{m}^{2}$ of package No. 1, which corresponds to the minimum investment with no economic incentives. This package and package No. 6 would probably attract the attention of potential property developers, who focus primarily on the initial investment, thus choosing solutions that are environmentally inefficient or can be significantly improved. 


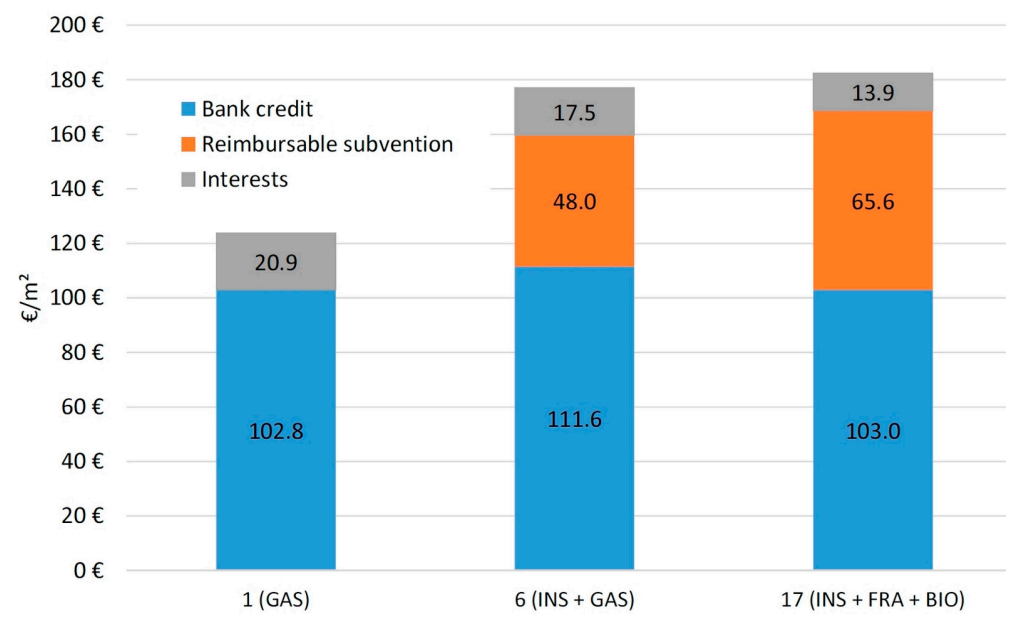

Figure 7. Initial investment required for working packages 1, 6, and 17 with financial support.

This comparison leads, therefore, to a need for redefining the quantity and the allocation method of financial incentives in such a way that the financial support discriminates between the renovation alternatives more precisely based on their environmental impact. Another option consists of imposing additional taxes on non-renewable energies such as piped gas, thus raising the energy cost and, consequently, the global cost of renovations that do not meet nZEB conditions. A simulation has been carried out considering an additional tax on piped gas of $32 \%$ in order to raise the global cost of No. 1 and 6 from 429 and $428 € / \mathrm{m}^{2}$ to 489 and $472 € / \mathrm{m}^{2}$, respectively. As can be seen in Figure 8 , these values are further from the $412 € / \mathrm{m}^{2}$ of No. 17 , so cost-optimal methodology would also help to choose the most efficient option.

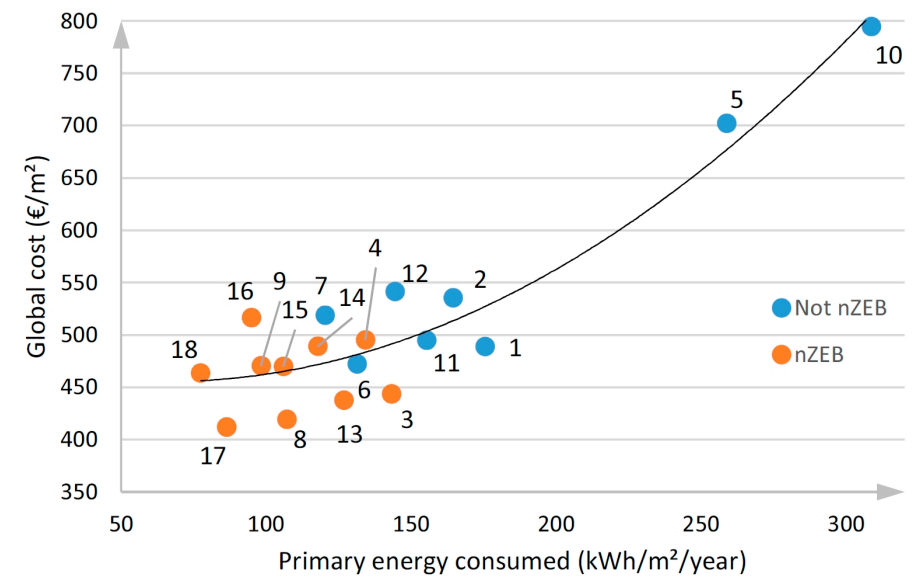

Figure 8. Global costs after including an additional tax of $32 \%$ on piped gas.

In order to take a decision based on more precise information, a deeper analysis of potential building renovations is recommended. To this end, one factor that should be considered in future research is the increase in the property value after being renovated [34,35]. Popescu et al. [36] calculated an average increase of $2 \%-3 \%$ after thermal retrofitting, according to the results from a survey on Romanian condominiums. Another valuable input would be the comfort parameters inside the buildings, such as temperature, humidity, noise, illumination levels, and air speed. Some of them are not easy to gather, as the perception of most of them greatly varies from user to user. Nevertheless, this information is still relevant to be aware of the real energy demand and consumption. 
The possible extrapolation of the results obtained in this article is limited by the analysis of a real case, which corresponds to a building constructed in the 1970s. Future analysis should focus on the modifications needed by buildings constructed during the other periods listed in Figure 2.

\section{Conclusions}

EU regulations are gradually moving towards policies that reduce energy consumption and its environmental impact. To reach this goal, improving energy efficiency in residential buildings is a key action line. Given that the majority of building stock is obsolete in terms of energy performance and that the renovation rate is roughly $1 \%$ per year, energy renovation becomes a sector that should be promoted. The European Parliament adopted the Near Zero-Energy Building as the energy efficiency paradigm, but a common technical and legislative framework for energy renovations is yet to be established.

In this paper the nZEB definition by COHERENO was adopted to evaluate several energy renovation packages in a given building, which is also representative of the Spanish building stock. Global costs are calculated for all of them following EPBD prescriptions. Two economic scenarios are analysed: one that is $100 \%$ privately funded and another that is partly financed by public financial incentives. The optimum solution, both in terms of energy performance and global costs, was carried out and described.

The global cost computation within the existing plan of financial support in Spain permitted us to detect the insufficiency of current economic incentives for energy renovations. This kind of programme is essential for the economic feasibility of nZEB renovations, so they should be kept after 2016 and even increased. The programme currently in force contributes to reduce global costs, but it is not enough to reduce the gap between the optimum solution in terms of energy savings and emissions and the optimum solution in terms of global costs. Furthermore, more active financial support, together with the dissemination of the technical requirements and the benefits obtained from energy renovations, would attract the attention of construction firms, property developers, and clients, still heavily focused on newly constructed buildings or unaware of the available technologies and benefits from energy renovations.

One possible line of action consists of directly reducing the initial investment by increasing non-refundable subsidies. A second approach consists of indirectly modifying the taxation of the least energy-efficient elements in buildings, in such a way that the economic interest of a package of energy renovation measures would be proportional to the improvement in the energy performance achieved. This can be accomplished, for instance, by increasing property taxes proportionally to the energy efficiency of the building, or by increasing taxes on energy sources depending on their environmental impact. These measures would contribute to reducing the current gap between the most energy-efficient solutions and cost-optimal renovations.

Acknowledgments: The authors would like to thank the Ministerio de Economía y Competitividad and the Centro para el Desarrollo Tecnológico Industrial (Government of Spain) for the financial support given through the ITC-20151012 project, co-funded by the European Regional Development Fund.

Author Contributions: Faustino Patiño Cambeiro conceived the methodology and performed the calculations. Renovation execution was performed by Faustino Patiño Cambeiro and Faustino Patiño Barbeito. Julia Armesto and Guillermo Bastos contributed to the writing of the paper.

Conflicts of Interest: The authors declare no conflict of interest.

\section{References}

1. Directive 2010/31/EU of the European Parliament and of the Council of 19 May 2010. Available online: http://www.buildup.eu/sites/default/files/content/EPBD2010_31_EN.pdf (accessed on 31 May 2016).

2. United Nations. Reports-Addendum part two: Action taken by the Conference of the Parties. In Proceedings of the Parties on Its Twenty-First Session, Paris, France, 30 November-13 December 2015; Available online: http://unfccc.int/resource/docs/2015/cop21/eng/10a02.pdf (accessed on 31 May 2016). 
3. Eichhammer, W.; Fleiter, T.; Schlomann, B.; Faberi, S.; Fioretto, M.; Piccioni, N.; Lechtenböhmer, S.; Schüring, A.; Resch, G. Study on the Energy Savings Potentials in EU Member States, Candidate Countries and EEA Countries. Final Report for the European Commission, Directorate-General Energy and Transport, 2009. Available online: https://ec.europa.eu/energy/sites/ener/files/documents/2009_03_15_ esd_efficiency_potentials_final_report.pdf (accessed on 31 May 2016).

4. BREEAM. BREEAM Refurbishment Domestic Buildings. Technical Manual SD5072-2012-3.2, 2012. Available online: http:/ / www.breeam.com/domrefurbmanual (accessed on 11 July 2016).

5. HQE. Available online: http://www.behqe.com (accessed on 11 July 2016).

6. Duarte Pinheiro, M.; Lider, A. Sistema Voluntário Para a Sustentabilidade dos Ambientes Construídos, 2011. Available online: http://www.lidera.info/resources/LiderA_Apresentacao_geral_2011_v1.pdf? phpMyAdmin=77d31a787ce126bb305b5b4b9dcec31c (accessed on 11 July 2016). (In Portuguese).

7. LEED 2009 for New Construction and Major Renovations. Available online: http://www.usgbc.org/Docs / Archive/General/Docs5546.pdf (accessed on 11 July 2016).

8. Kylili, A.; Fokaides, P.A.; Lopez Jimenez, P.A. Key Performance Indicators (KPIs) approach in buildings renovation for the sustainability of the built environment: A review. Renew. Sustain. Energy Rev. 2016, 56, 906-915. [CrossRef]

9. D'Agostino, D. Assessment of the progress towards the establishment of definitions of Nearly Zero Energy Buildings (nZEBs) in European Member States. J. Build. Eng. 2015, 1, 20-32. [CrossRef]

10. Dineva, D.; Boucher, J.; Heeren, N.; Wallbaum, H.; Wunderlich, A. Pathways towards an energetic refurbishment replication strategy for eastern European countries-Findings from the EU project BEEM-UP. In Proceedings of the Sustainable Building 2014, Barcelona, Spain, 28-30 October 2014.

11. Ferrante, A. Energy retrofit to nearly zero and socio-oriented urban environments in the Mediterranean climate. Sustain. Cities Soc. 2014, 13, 237-253. [CrossRef]

12. Hamdy, M.; Hasan, A.; Siren, K. A multi-stage optimization method for cost-optimal and nearly-zero-energy building solutions in line with the EPBD-recast 2010. Energy Build. 2013, 56, 189-203. [CrossRef]

13. Becchio, C.; Dabbene, P.; Fabrizio, E.; Monetti, V.; Filippi, M. Cost optimality assessment of a single family house: Building and technical systems solutions for the nZEB target. Energy Build. 2015, 90, 173-187. [CrossRef]

14. European Council for an Energy Efficient Economy. Understanding (the very European Concept of) Nearly Zero-Energy Buildings, Steering through the Maze \#2 (revised): A Guide from the ECEEE, 2014. Available online: http://www.eceee.org/policy-areas/Buildings/nearly-zero-energy-buildings/nZEB-maze-guide. pdf (accessed on 31 May 2016).

15. Ecofys. Towards Nearly Zero-Energy Buildings, Definition of Common Principles under the EPBD, Final Report, 2013. Available online: https://ec.europa.eu/energy/sites/ener/files/documents/nzeb_full_ report.pdf (accessed on 31 May 2016).

16. Department of Communities and Local Government (UK). Code for Sustainable Homes, Technical Guide, 2010. Available online: https://www.gov.uk/government/uploads/system/uploads/attachment_data/ file/5976/code_for_sustainable_homes_techguide.pdf (accessed on 31 May 2016).

17. Barthelmes, V.M.; Becchio, C.; Bottero, M.C.; Corgnati, S.P. The influence of energy targets and economic concerns in design strategies for a residential Nearly-Zero Energy Building. Buildings 2014, 4, 937-962. [CrossRef]

18. Serghides, D.K.; Dimitriou, S.; Katafygiotou, M.C.; Michaelidou, M. Energy efficient refurbishment towards nearly zero energy houses, for the Mediterranean Region. Energy Procedia 2015, 83, 533-543. [CrossRef]

19. Oliveira Panão, M.J.N.; Rebelo, M.P.; Camelo, S.M.L. How low should be the energy required by a nearly Zero-Energy Building? The load/generation energy balance of Mediterranean housing. Energy Build. 2013, 61, 161-171.

20. Lindkvist, C.; Karlsson, A.; Sørnes, K.; Wyckmans, A. Barriers and challenges in nZEB projects in Sweden and Norway. Energy Procedia 2014, 58, 199-206. [CrossRef]

21. Buildings Performance Institute Europe (BPIE). NZEB Criteria for Typical Single-Family Home Renovations in Various Countries; International Report; Intelligent Energy Europe Project COHERENO: Berlin, Germany, 2013; Available online: http://bpie.eu/wp-content/uploads/2015/11/nZEB_Criteria_for_renovation_ COHERENO.pdf (accessed on 31 May 2016). 
22. Commission Delegated Regulation (EU) No. 244/2012 of 16 January 2012, Supplementing Directive 2010/31/EU. Available online: http://www.buildup.eu/sites/default/files/content/1_ 08120120321en00180036.pdf (accessed on 31 May 2016).

23. Cuchí, A.; Sweatman, P.; Working Group for Rehabilitation (GTR). A national perspective on Spain's Buildings Sector. A Roadmap for a New Housing Sector, 2011. Available online: http:/ /www.gbce.es / archivos/ckfinderfiles/Investigacion/libro_GTR_engl_postimprenta.pdf (accessed on 31 May 2016).

24. Kmet'ková, J.; Krajčík, M. Energy efficient retrofit and life cycle assessment of an apartment building. Energy Procedia 2015, 78, 3186-3191. [CrossRef]

25. Davis Langdon Management Consulting. Literature Review of Life Cycle Costing (LCC) and Life Cycle Assessment (LCA), 2006. Available online: http://www.tmb.org.tr/arastirma_yayinlar/LCC_Literature_ Review_Report.pdf (accessed on 12 July 2016).

26. International Standard. Buildings and Constructed Assets. Service-Life Planning. Part 5: Life-Cycle Costing; ISO 15686-5:2008; International Organization for Standardization: Geneva, Switzerland, 2008.

27. Marszal, A.J.; Heiselberg, P. Life cycle cost analysis of a multi-storey residential Net Zero Energy Building in Denmark. Energy 2011, 36, 5600-5609. [CrossRef]

28. Tanasa, C.; Sabau, C.; Stoian, D.; Dan, D.; Stoian, V. Study on the Life Cycle Cost of energy efficient residential buildings. In Proceedings of the 3rd International Conference on Agricultural Science, Biotechnology, Food and Animal Science (ABIFA 2014), Brasov, Romania, 26-28 June 2014; pp. 173-179.

29. Sesana, M.M.; Salvalai, G. Overview on life cycle methodologies and economic feasibility for nZEBs. Build. Environ. 2013, 67, 211-216. [CrossRef]

30. Olsson, S.; Malmqvist, T.; Glaumann, M. An approach towards sustainable renovation-A tool for decision support in early project stages. Build. Environ. 2016, 106, 20-32. [CrossRef]

31. Pombo, O.; Rivela, B.; Neila, J. The challenge of sustainable building renovation: Assessment of current criteria and future outlook. Clean. Product. 2016, 123, 88-100. [CrossRef]

32. Bonazzi, G.; Iotti, M. Evaluation of investment in renovation to increase the quality of buildings: A specific Discounted Cash Flow (DCF) approach of appraisal. Sustainability 2016, 8, 268. [CrossRef]

33. Energy Diversification \& Saving Institute (IDAE). Guidelines for the Financial Support Program for Existing Buildings Renovations PAREER-CRECE, 2013. Available online: http:/ /www.idae.es/uploads / documentos/documentos_PAREER-CRECE-texto_refundido_y_consolidado_478cfff4.pdf (accessed on 31 May 2016).

34. Dall'O, G.; Belli, V.; Brolis, M.; Mozzi, I.; Fasano, M. Nearly zero-energy buildings of the Lombardy region (Italy), a case study of high-energy performance buildings. Energies 2013, 6, 3506-3527. [CrossRef]

35. Tadeu, S.F.; Alexandre, R.F.; Tadeu, A.J.B.; Antunes, C.H.; Simões, N.A.V.; Silva, P.P.D. A comparison between cost optimality and return on investment for energy retrofit in buildings. A real options perspective. Sustain. Cities Soc. 2016, 21, 12-25. [CrossRef]

36. Popescu, D.; Bienert, S.; Schützenhofer, C.; Boazu, R. Impact of energy efficiency measures on the economic value of buildings. Appl. Energy 2012, 89, 454-463. [CrossRef]

(c) 2016 by the authors; licensee MDPI, Basel, Switzerland. This article is an open access article distributed under the terms and conditions of the Creative Commons Attribution (CC-BY) license (http://creativecommons.org/licenses/by/4.0/). 